\title{
Prédios "neoclássicos" no espaço residencial das elites de São Paulo ${ }^{1}$
}

\author{
CAROLINA PULICI I
}

"Em ordens sociais de extrema mobilidade, é comum que as pessoas sejam extremamente sensíveis em relação a tudo o que possa ameaçar sua posição. É comum que elas desenvolvam angústias ligadas ao status." (Norbert Elias e John Scotson, Os estabelecidos e os outsiders).

\section{Introdução}

A PRODUÇão de prédios "neoclássicos" na arquitetura doméstica paulistana se inscreve num subcampo do espaço da arquitetura que se define tanto em relação à arquitetura como um todo quanto em relação aos demais produtores desse partido arquitetônico. Tendo como marco inicial o edifício São Luiz, projetado em 1944 pelo arquiteto francês Jacques Pilon (19051962 ) - que "parece ter inaugurado, portanto, a onda de edifícios residenciais neoclássicos que até hoje assola a cidade" (Pinheiro, 2008, p.137) -, os promotores desse tipo de projeto situaram-se, posteriormente, na construtora de Alfredo Mathias, fundada em 1950 e, sobretudo, na de Adolpho Lindenberg, criada em 1953 e voltada ao segmento residencial de alto padrão em bairros como Jardins e Higienópolis (Leite, 2006). Igualmente consagradas segundo a hierarquia do mercado, as construtoras Gomes de Almeida Fernandes, Kauffman, Tecnisa, São José, Cyrela, JHS-F, R. Yazbek estão, na atualidade, entre os agentes encarregados da produção e circulação desses bens simultaneamente estéticos e comerciais.

Levando-se em conta as principais clivagens que atravessam o campo da arquitetura, pode-se dizer que os promotores do "neoclássico" dispõem de maior facilidade de acesso às encomendas privadas, mas, a um só tempo, de menor reconhecimento simbólico, uma vez que estão mais afastados da definição mais legítima de arquitetura e de uma cultura profissional que seria específica do arquiteto. Renunciando aos predicados mais exclusivos da profissão, eles realizam as obras que menos servem de modelo aos estudantes de arquitetura, as menos celebradas pelas instâncias de reconhecimento do campo (revistas especializadas, concursos e prêmios) e as menos tendentes a angariar um lugar futuro na história da arquitetura. ${ }^{2}$

De acordo com boa parte da crítica de arquitetura, os prédios "neoclássi- 
cos" que se propagaram na paisagem urbana paulistana na segunda metade do século XX exprimem a imitação grosseira de uma linguagem anacrônica - e politicamente comprometida (Serapião, 2011) -, priorizando a "embalagem nobre" sedutora de uma elite de "dinheiro novo" disposta a comprar um passado glorioso (Helvécia, 2008). "Fraudulentos", tais edifícios ostentariam uma "volumetria desconcertante" e misturariam, inadvertidamente, elementos das ordens clássicas com balaústres, pináculos e mansardas (Serapião, 2004). Prolonga-se, assim, na atualidade, o combate que Gregori Warchavchik (2006) dirigiu à "triste decadência do gosto" representada pela cópia espúria de arquiteturas antigas, denunciando-se a servidão às leis mercadológicas responsáveis pela degradação do fazer arquitetônico (Villa, 2006).

Ainda que tais críticas apontem para o sentido geral da evolução de todas as atividades sociais na contemporaneidade, crescentemente submetidas aos processos de mercantilização, pouco se discutiu, até o momento, o processo coletivo de consagração desse bem econômico e simbólico que se viabiliza malgrado todos os desvirtuamentos apontados. Admitindo-se a dupla natureza dos bens simbólicos, tem-se que os circuitos de produção e circulação material são também ciclos de consagração que produzem legitimidade (Bourdieu; Delsaut, 2006) e, assim, o princípio da eficácia dos prédios "neoclássicos" não pode ser buscado apenas em suas características intrínsecas, mas nos condicionantes que produzem a crença nesse modelo residencial. Se o mercado define, em ampla medida, a paisagem de uma cidade, ele também exprime, não raro - e como mostrou Carl Schorske (1981, p.47) a respeito da habitação promovida pela classe vienense em ascensão social a partir de 1860 -, a intersecção de interesses econômicos e valores culturais dos grupos afortunados. ${ }^{3}$

Nessa linha de juízo, o estudo da consagração social desse gosto controverso impõe que se discuta não tanto a autoria dos projetos em questão, mas os valores dos principais interessados em sua produção e difusão. Em vista dessas considerações, o texto que segue analisará os discursos e representações de arquitetos, engenheiros, construtores, paisagistas e corretores imobiliários implicados na consolidação dessa proposta de habitação, centrando o foco no que produzem e nas declarações e profissões de virtude a respeito dessa produção. Com base em sete entrevistas realizadas com esses profissionais dotados do poder social de construir, no material de imprensa (crítica de arquitetura, informes publicitários e sites de construtoras e corretoras imobiliárias) veiculado em São Paulo a partir do ano 2000 e na bibliografia voltada ao problema do historicismo em arquitetura, argumenta-se que, se, por um lado, tal partido arquitetônico é consagrado pela sociedade, ocupando uma posição dominante do ponto de vista da hierarquia do mercado, por outro, o descrédito que lhe é atribuído pelos detentores da legitimidade arquitetônica (Martí; Barros, 2009) o condena a uma posição dominada do ponto de vista de um reconhecimento propriamente simbólico. 


\section{Os emblemas dos edifícios: clientelas e metáforas sociais}

Em maio de 2011 a Folha de S.Panlo anunciou o fim da "ditadura do neoclássico" e a perda de espaço dos edifícios de fachadas ornamentadas para os prédios filiados à linguagem contemporânea. Tendo entrevistado arquitetos e construtoras, a reportagem desautoriza a explicação despolitizada da "pura percepção estética" para dar conta dos padrões de gosto de uma sociedade e de uma época, revelando que a eficácia dessa opção de moradia deveu-se a fatores extraestéticos e, precisamente, às estratégias distintivas vigentes nas relações de classe: "Com suas colunas e ornamentos, o estilo neoclássico foi muito procurado porque dava impressão de ser de mais alto padrão" (Correa, 2011, p.Cl). Em vista disso, a abordagem desses prédios não do ponto de vista de uma história da arquitetura atenta aos aspectos estilísticos e técnicos das construções, mas a partir dos valores e atitudes de seus construtores (e, através deles, de suas clientelas) nos conduz a passar em revista, a seguir, toda uma série de metáforas sociais recorrentemente associadas a essa arquitetura.

A análise dos discursos emitidos pela construtora mais associada a essas edificações - a Adolpho Lindenberg - permite acompanhar o modo como tal proposta habitacional buscou apresentar-se como emblema de distinção e de bom-gosto. Se um profissional do mercado imobiliário tem tanto mais chance de ganhar um cliente quanto maior for a proximidade social entre ambos (Bourdieu, 2000; Bernard, 2012), entende-se por que o livro comemorativo dos cinquenta anos da empresa destaca a origem social elevada de seu criador e sua trajetória bem-sucedida junto às elites paulistanas. Segundo a publicação, sua família está no Brasil desde 1818 e cada geração fez um percurso inédito e exitoso. O patriarca, engenheiro alemão, é retratado como um dos pioneiros da indústria salineira de Cabo Frio; o pai do fundador da Construtora Adolpho Lindenberg (CAL), dermatologista especializado em Berlim, Viena e Paris, figura como o primeiro professor catedrático e instituidor de tal especialidade médica na Santa Casa de São Paulo. Sua esposa é apresentada como "descendente de uma família paulista tradicional". Formado em Engenharia e Arquitetura no Mackenzie, Adolpho Lindenberg teria estudado alemão "desde os primeiros anos" e tido uma infância na qual "as viagens à Europa e referências culturais do Velho Mundo estiveram muito presentes" (Visoni; Mourão; Reinés, 2004, p.22). Apesar de ter iniciado uma carreira "promissora" como engenheiro de "uma companhia de excelente reputação", "o empreendedorismo foi mais forte", levando-o a investir sua herança na criação de seu próprio negócio. Nos anos 1950, "combinando seu gosto pessoal com a tendência estilística do momento", teria tido sucesso na venda de suas primeiras casas neocoloniais, dedicando-se também à restauração de fazendas do período cafeeiro. Na condição de "um dos mais renomados construtores de casas de luxo no país", ele seria o mais preparado para atuar no ramo de apartamentos de alto padrão, conhecendo como poucos os "deveres de representação" (Elias, 2001) a que se submetem as clientelas afor- 
tunadas a fim de preservar sua respeitabilidade social: "Lindenberg se recorda de que entre os proprietários havia grande preocupação em não dar a entender que a família estaria vendendo sua casa para morar num apartamento menor devido a uma crise financeira" (Visoni; Mourão; Reinés, 2004, p.26).

\section{PRINCESA IMPERIAL}

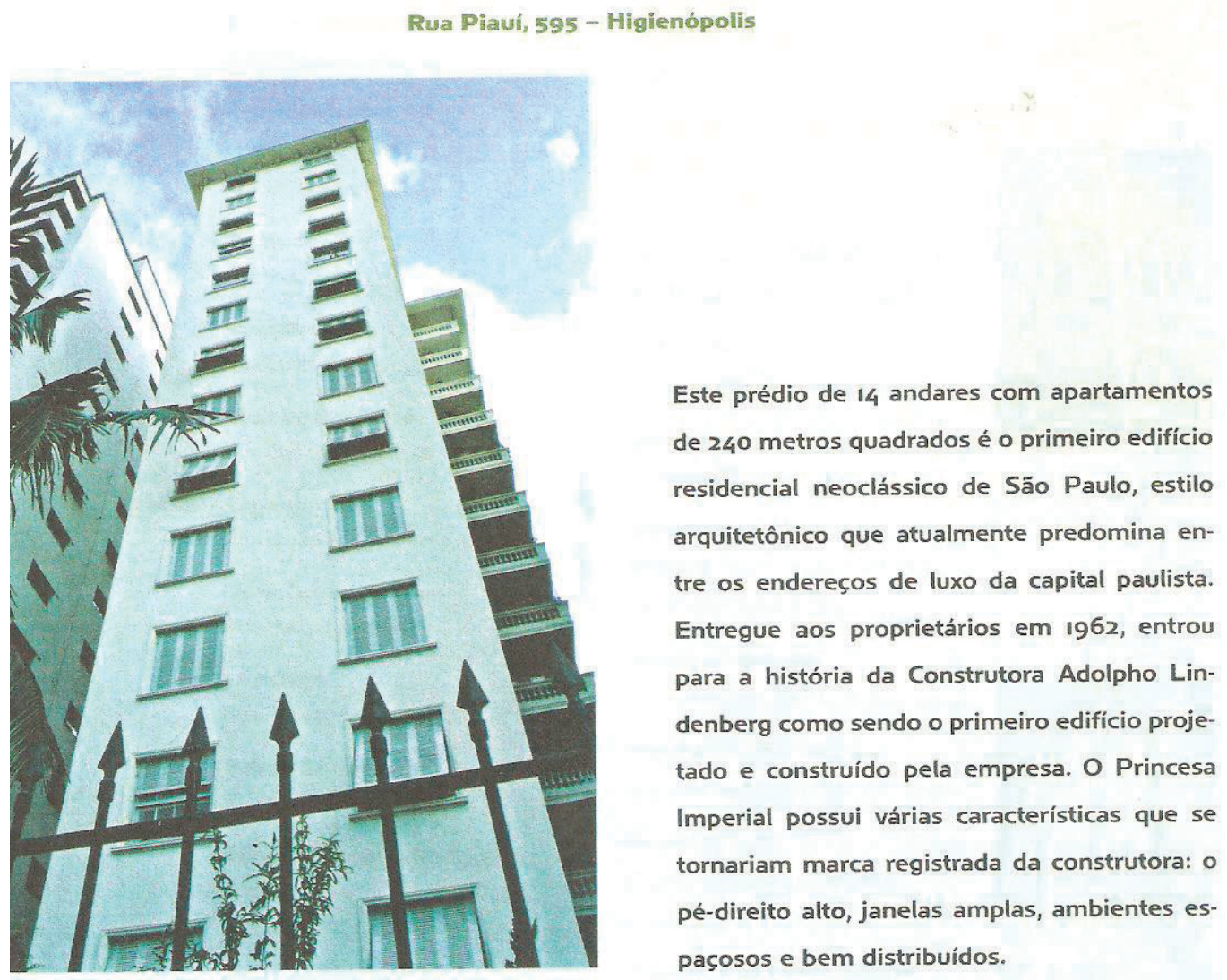

\section{Fabricação de tradições}

O livro comemorativo dos cinquenta anos da CAL afirma o pioneirismo de Adolpho Lindenberg na propagação do "estilo" hoje presente na maioria dos edifícios residenciais de alto padrão ("O que foi pioneirismo transformou-se em moda" (Visoni; Mourão; Reinés, 2004, p.127)), apesar de Jacques Pilon e Alfredo Mathias já terem projetado edifícios residenciais “neoclássicos” em São Paulo (em 1944 e 1949, respectivamente). 
Nesse livro dedicado à celebração da construtora que teria erguido quatrocentos edifícios e duzentas casas, as analogias com o mundo da arte são abundantes: seus prédios consistiriam em "uma obra de autor" e seus departamentos em equipes impulsionadas "pela ideia arquitetônica", num contexto institucional em que, "do começo ao fim da obra, a prioridade será dada à estética". Os edifícios da CAL são apresentados como "construções que atravessam o tempo envelhecendo como vinhos", tendo "suas virtudes realçadas com o passar dos anos".

\section{$\mathrm{O}$ apelo às categorias históricas como argumento de venda}

"Seguramente um dos estilos arquitetônicos mais bem-sucedidos de todos os tempos, o neoclassicismo tem a rara qualidade de remeter às civilizações grega e romana e aos monumentos clássicos da humanidade sem sucumbir ao exagero e à ostentação. Sua característica principal são elementos decorativos, que derivam direta ou indiretamente do vocabulário arquitetônico da Antiguidade. É a estética da "nobre simplicidade e serena grandeza", como definiu o estudioso alemão Johann Joachim Winckelmann. Sua arte é tão universal que transcende distâncias geográficas. Existem conjuntos arquitetônicos neoclássicos significativos em latitudes e longitudes tão variadas quanto Paris, Buenos Aires, São Petersburgo, Havana, Washington, Helsinque, Macau e Lima. A clara influência da arquitetura grega - com seus arcos, colunas, cornijas, frontões, pórticos, rigorosas proporções, simetria, parcimônia nas cores - é assimilada não como uma reles imitação, mas como a renovação do espírito da Antiguidade. Um salto para o futuro que tem como base de lançamento os puros, sólidos e democráticos princípios do mundo helênico. É claro que nem sempre se está atento a todo o contexto histórico ao admirar uma bela fachada neoclássica. Mas também o neoclássico não nos encanta apenas porque remete aos edifícios parisienses. Mesmo inconscientemente, apreciamos o estilo porque suas construções materializam a tradição e elegância de várias civilizações. A escolha do neoclássico como tema principal de seus empreendimentos baseou-se em grande parte no gosto pessoal de Lindenberg, que em viagens para a Europa, mesmo quando criança, se encantou com a força desse estilo." (Visoni; Mourão; Reinés, 2004, p.45)

Indagada sobre as razões pelas quais tal proposta de habitação teria tido êxito, uma arquiteta e gerente de projetos da CAL avaliou que quando Adolpho Lindenberg começou a fazer tais prédios, seus clientes eram os ricos tradicionais que iam para a Europa e voltavam querendo morar "com a cara de Paris, com a cara europeia'". Associada ao continente europeu (e à vida aristocrática que supostamente simboliza), essa forma de moradia estaria apta a satisfazer os anseios de prestígio da clientela abastada ("socialmente, você parece que está mais elevado"). Com o passar dos anos, entretanto, setores emergentes teriam aderido a esse modelo residencial, de modo que seria difícil decidir se esse é um gosto típico dos que, advindos de famílias antigas possuidoras de casarões neocoloniais ou mansões neoclássicas, seriam afeitos a uma arquitetura verticalizada que fosse 
também histórica e ornamentada, ou, no extremo oposto - e como quer a crítica de arquitetura -, daqueles que tiveram “começos difíceis" e estão às voltas com a criação de uma antiguidade através da arquitetura.

Seja como for, o imaginário de Paris reaparece em diversos momentos da entrevista:

Uma vez eu recebi um garoto, isso há muitos anos atrás, ele fazia medicina, era novinho, devia ser de família rica. E ele estava [...] saindo de um apartamento de $250 \mathrm{~m}^{2}$ - acho que tinha $300 \mathrm{~m}^{2}$ o apartamento dele -, para comprar um Lindenberg, que era o sonho dele, ali nos Jardins, que tinha acho que uns 150 e poucos, era um dos pequenos. Mas daquela época, antigo [...]. Porque ele ia para, ele gostava de Paris, ia para Paris, gostava daquela arquitetura, e ele queria morar num lugar igual, sabe? E aí ele procurou saber, ele descobriu que na Lindenberg os edifícios antigos tinham essa cara e aí ele ficou na fila lá de um, saiu e ele foi e vendeu o apartamento dele de $300 \mathrm{~m}^{2}$ para comprar esse. (Entrevista realizada em 13.6.2012)

Tendo afirmado que tanto as classes altas tradicionais quanto as recém-enriquecidas residem nos "neoclássicos" paulistanos, um engenheiro civil atuante na Secretaria Municipal de Habitação, antigo gerente de negócios da Tecnisa e autor de um mestrado sobre as estratégias das empresas incorporadoras de São Paulo, acredita, contudo, que os assim chamados novos-ricos tendem a procurar referências que, de um ponto de vista cultural, os posicionem no mesmo nível já alcançado em termos econômicos:

E as referências históricas que a gente tem são... tem muitas referências neoclássicas; está lá o Museu do Ipiranga, né, o Museu do Ipiranga que é um marco para a cidade, ele é neoclássico [...]. Então, as referências que as pessoas buscam [são] padrões elevados... Eu acho que Paris tem uma grande responsabilidade - a França até - nesse assunto [...], eu acho que as pessoas vão buscar essa referência. (Entrevista realizada em 25.6.2012)

Ecoando a tese de que o público se compraz diante de elementos arquitetônicos "marcados pela História" (cornijas, pilastras, frontões etc.) (Biau, 2000) ou, ainda, a do vigor dos hábitos perceptivos (Gombrich, 2003), ele nota que “[...] o império romano e o grego, que eram sociedades bem-sucedidas, tinham essas referências". Tendo atuado em construtora não reconhecida pelos meios intelectuais e artísticos, ele sublinha que a opinião dominante no mercado imobiliário é a de que quem decide é o cliente. E este, por sua vez - e como mostrou Schorske (1981, p.50-1) para o caso de Viena -, seria muito receptivo à adaptação de elementos da arquitetura palaciana na arquitetura de apartamentos:

Eu já vi briga, briga feia mesmo entre um arquiteto que é excelente, moderno, com o dono de uma imobiliária. Num projeto meu. Porque um queria uma coisa e o outro não queria. E o dono da imobiliária, que é um cara até muito moderno, queria uma coisa muito mais conservadora $[\ldots]$; quando você sai do elevador - era um apartamento de 200 metros assim, 
sei lá - em geral você tem aqui a porta de entrada, tem o hall do elevador aqui, e aí quando você sai, aqui tem a sala. Então o da imobiliária, o dono da imobiliária, ele queria que fizesse um hall aqui, pusesse um pilar aqui e não sei o quê para criar um ambiente, uma referência [...]; e o arquiteto: "é uma bobagem, vai perder espaço, tira isso aqui e já incorpora na sala e tal”, porque o arquiteto era moderno; é moderno. Então, por que é que o cara queria essa referência aqui, entendeu? Porque quando você entra numa casa do Jardim Europa tem isso aqui, o vestíbulo, ou você entra num palácio, tem isso aqui, onde ficam as pessoas no cerimonial, recebendo.

Um paisagista atuante nos mais luxuosos residenciais "neoclássicos” da cidade - como os erguidos pela São José ${ }^{4}$ - também avaliou que as fachadas “neoclássicas" têm apelo em São Paulo por remeterem ao "Velho Mundo", com tudo o que ele inspira de "chiqueria", para usar os seus próprios termos. Como Durkheim (1996, p.237), que postulou que o caráter sagrado de uma coisa não decorre de suas propriedades intrínsecas, ele sugere que as virtudes desses prédios advêm dos sentimentos que eles evocam e simbolizam: "Paris. Paris é chique. Milão. Milão é chique” (entrevista realizada em 25.6.2012). O paisagismo próprio a tais empreendimentos segue a arquitetura histórica: "Então tem bastante topiaria, tem lavanda, é um jardim europeu, né? Às vezes puxando um pouco para a Provence, um pouco para a Toscana, escola italiana, escola francesa, mas sempre tende a ir para essa linguagem paisagística". Se “o paisagismo é a moldura da arquitetura", a entrada dessas edificações é invariavelmente "suntuosa" e o uso de fontes muito bem-vindo. Além de caminhos, praças, bancos e jardim geométrico, pode-se criar um "ar mais tropical” recorrendo a palmeiras, "[...] porque tem isso também no sul da França. Saint-Tropez, na Provence, tem... [está] cheio de Palmeiras em jardins franceses". Mas o aspecto palaciano e monumental é sempre o tom dominante nesses residenciais. Mesmo sendo qualificado para difundir várias expressões paisagísticas (francesa, italiana, japonesa e tropical), no cômputo geral recebe mais encomendas de jardins franceses e italianos, de modo que tal gosto legitimado "pela marca do "europeísmo"” (Reis Filho, 1987) não seria exclusivo dos prédios "neoclássicos".

No seu entender, tais edifícios têm o mérito de possuir uma proposta estética, gostemos dela ou não. O mesmo não poderia ser dito da quase totalidade das construções que compõem a paisagem paulistana, e é justamente a falta de identidade da maioria dos prédios ("não é nada, é uma economia de construtora") o que destacaria as fachadas ornamentadas: "Eu acho que aí é conclusivo, por uma falta de identidade é que o neoclássico se sobressai. Porque os outros não são nada [...]. Não tem proposta!". Tal visão coincide com o argumento de que toda edificação se beneficia da mediocridade de seu entorno (Loyer, 1987, p.141).

Para um arquiteto formado na FAU-USP (e proprietário do escritório responsável pelos projetos dos prédios “neoclássicos” produzidos pela Kauffman), 
Le Crillon: a classe dos Jardins - "Ocupando posição inigualável na famosa Place de la Concorde em Paris, o Hotel de Crillon, um dos mais requintados do mundo, foi a inspiração para a concepção do projeto na região dos Jardins, o Le Crillon. Situado na rua Peixoto Gomide, o empreendimento está no meio de tudo o que a cidade tem de melhor: restaurantes famosos, butiques da moda e joalherias de renome. Implantado em um dos últimos terrenos da região com mais de $4.000 \mathrm{~m}^{2}$, o estilo neoclássico de sua fachada, projetada por Itamar Berezin, convive com o luxo contemporâneo. São duas sofisticadas torres de vinte andares. No edifício Rivoli, os apartamentos são de três dormitórios, sendo um suíte com 107 $\mathrm{m}^{2}$ privativos. No edifício Royale, os apartamentos são de quatro dormitórios, sendo dois suítes com $139 \mathrm{~m}^{2}$ privativos. Ambos com as áreas bem distribuídas e a sala de jantar e o living integrados a um extenso terraço e duas ou três vagas na garagem. A nobreza do projeto continua nas áreas sociais. Os elegantes halls sociais para receber moradores e visitantes foram decorados pelo arquiteto Sig Bergamin e pela decoradora Teresinha Nigri”. ${ }^{5}$

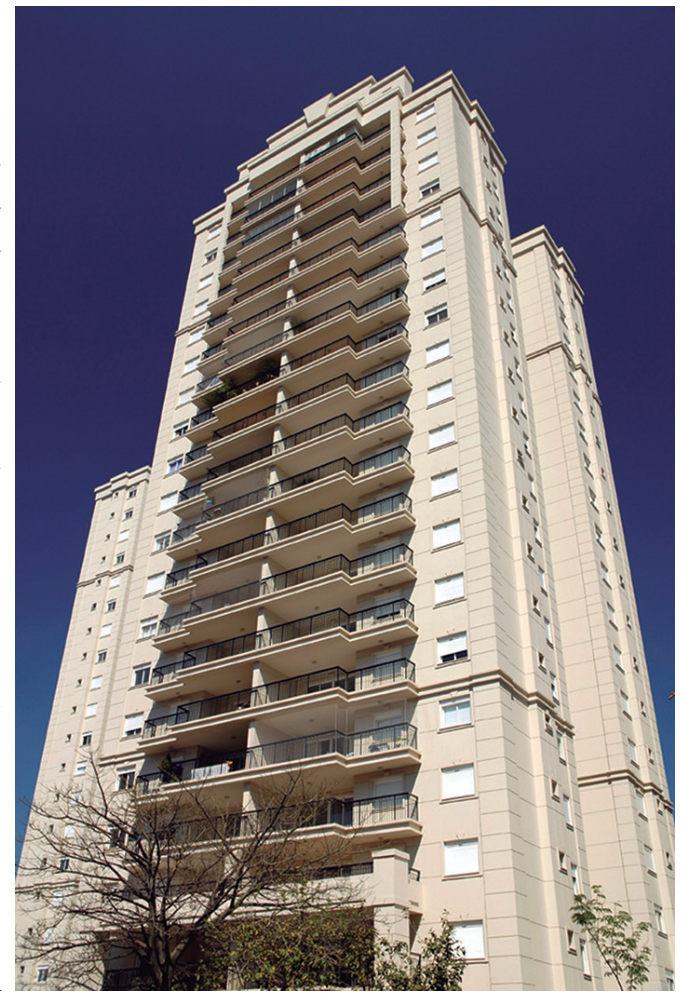

a presença desses edifícios em São Paulo estaria ligada a Adolfo Lindenberg e à "tradição da família paulista", o que teria levado a que grupos médios se espelhassem em tal referência em busca de ascensão social. A esse respeito, seus nomes - que alternam entre castelo, palácio e mansão, escritos em francês e, no caso da Kauffman, italiano - seriam emblemáticos: "É a referência do que é chique, do que é nobre, não tem jeito" (Entrevista realizada em 14.6.2012). No que tange às artimanhas empregadas para aumentar a atratividade visual dos imóveis, ele destaca o frontão no coroamento e o embasamento em arcadas, lembrando que o público associaria o pé direito alto dos halls de entrada aos castelos, com toda a conotação de suntuosidade.

Um arquiteto-paisagista (proprietário de um escritório que trabalha para as construtoras que produzem "neoclássicos") revela conceber projetos harmônicos, com espelhos d'água mais simétricos e cuja esplanada cumpra sua função de monumentalidade. Ciente de que sua atuação não depende apenas de coerência formal, ele assume não ignorar as "angústias ligadas ao status" - para falar como Elias e Scotson (2000) - de sua clientela: 


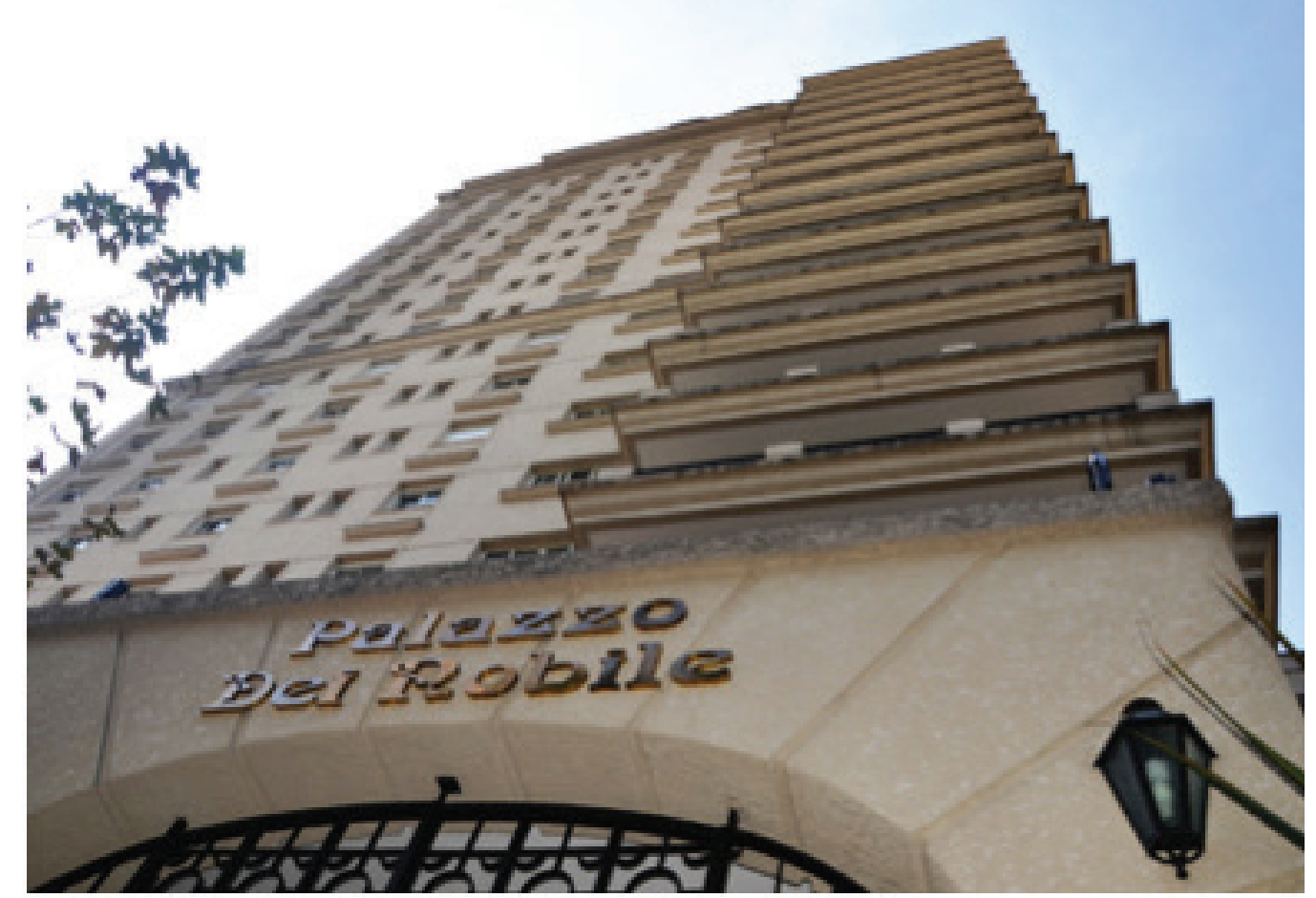

Foto do Edifício Palazzo Dei Nobile, da Construtora Kauffman, no Itaim. ${ }^{6}$

[...] a pessoa precisa chegar e falar "uau, que bacana" [...]; então sempre eu procuro fazer uma coisa mais monumental para atender à função da monumentalidade, para eu conseguir esse... no fundo é um status para as pessoas que moram [...], uma imponência, porque eu acho que isso no fundo é uma coisa que as pessoas gostam. (Entrevista realizada em 22.6.2012)

Ao nos mostrar o paisagismo criado para um residencial "neoclássico" que se encontra na lista dos dez imóveis mais caros de São Paulo, ele sublinha a presença de "porte cochère":

Você vê, é grande a entrada principal, você vê o tipo de vegetação. Mas o que é que eu tenho aqui no térreo? Eu tenho um grande estacionamento. Por quê? Porque as pessoas querem mostrar os seus carros, está certo? Eu vou visitar o meu amigo, eu quero mostrar o meu novo porsche, que eu acabei de comprar.

Sobre as artimanhas empregadas para enobrecer a fisionomia desses edifícios, ele menciona algo já apontado pelos trabalhos sobre o gosto do público da arquitetura (Barbe; Duclent, 1986; Bourdieu, 2000; Eleb; Nivet; Violeau, 2005), isto é, que a pré-fabricação de elementos e cenários tradicionais goza de amplo reconhecimento social: 
Você veja, por exemplo, esses pilares. Para serem funcionais, eles poderiam ter 10 por 10 . E eles têm 50 por 50 . Por que é que eles têm 50 por 50 ? Por que é que eu tenho que fazer um pilar de 10 por 10 e depois colocar um granito que faz uma caixa de 50 por 50 e que não tem função? Por que é que eu uso uma luminária [...] [que] tem uma cara antiga?

Grandes espelhos d'água e pérgulas também fazem parte dos artifícios de embelezamento usados nos projetos paisagísticos desse feitio. E “artifício" no sentido literal, como quando nos mostra um falso portal destinado a separar dois empreendimentos e, a um só tempo, criar uma impressão de continuidade: "Isso é uma coisa que o pessoal da FAU tem horror! [...], a gente fez um gradil para dar a sensação de transparência e pusemos um grande portal aqui. Só que isso aqui é de mentira". Assim, contrariamente aos princípios modernistas que primam pela "verdade dos materiais", os edifícios em pauta exigem que seus promotores recorram aos materiais construtivos modernos, mas em vestes históricas e de modo a atender a fins de representação. Ou seja, os novos materiais construtivos são assimilados não segundo os princípios do funcionalismo, mas de uma tradicional forma de expressão arquitetônica.

Pesquisador: A fachada conta tanto quanto a disposição dos espaços internos ou ela é de somenos importância quando comparada à localização?

Informante: Veja bem, eu acho que são objetivos diferentes, está certo? A fachada é um grande outdoor, que eu coloco e mostro para os meus amigos [...]. É importante, ela atende à questão do status. E o status é uma coisa importante, eu não estou falando de status no sentido de preconceito [...]. Prestígio, se sentir honrada, sentir que ela fez um grande sacrifício na vida e ela conseguiu. Então essa questão de status é fundamental, porque é a coisa externa, é como eu me apresento para a sociedade, é como eu me apresento no meu entorno.

Certo de que a arquitetura doméstica não escapa às expectativas de honra social dos moradores, ele avalia que o mercado nutre tais anseios de distinção em tudo contrários aos princípios urbanísticos que zelam pela harmonia entre as construções. Apesar de os informes publicitários recorrerem à arquitetura parisiense como argumento de venda, as apostas urbanísticas locais em nada lembrariam o alinhamento e a impregnação das fachadas no plano do conjunto que são típicos da capital francesa (Bailly, 1987), pois “[...] o que você tem é 'Pô, eu quero ser um pouco mais do que o meu amigo, então o meu prédio tem que ser mais bacana do que o prédio do outro"'.

No que tange às clientelas preferenciais desses empreendimentos, esse profissional que comanda o escritório atuante no projeto de alguns dos edifícios "neoclássicos" mais caros da cidade - como o L'Essence, localizado nos Jardins, cuja cobertura está avaliada em 24,7 milhões de reais, ou o outro L'Essence, situado na Vila Nova Conceição, cuja cobertura custa 40 milhões de reais (Wiltgen, 
2012) - pondera: "Eu acho que tem dos dois públicos [pessoas recém-enriquecidas e oriundas de famílias antigas] [...]. Eu vejo o seguinte, às vezes o cara nem gosta do neoclássico, mas ele entende que aquilo é uma coisa que vai perdurar". Mas se nesse ponto seu relato indica que tal preferência exprime o apego aos valores seguros ("o neoclássico não incomoda"), em outros momentos sugere que esse gosto testemunharia o desejo de criação de uma antiguidade através da arquitetura: "Quem gosta são as pessoas que querem ter uma sensação de tradição". 7 Apesar de discordar da crítica de arquitetura para a qual esse gosto seria exclusivo dos assim chamados novos-ricos, ele reconhece que há muita gente recém-enriquecida no Brasil contemporâneo que vai morar no L’Essence, “[...] gente que precisa chamar alguém para arrumar a mesa de jantar". ${ }^{8}$

Desafiando a frequente associação entre prédios "neoclássicos" e setores recém-enriquecidos, um corretor especializado no comércio de imóveis de luxo aposta que esse gosto seria especialmente difundido entre os "paulistas de quatrocentos anos" (Trigo, 2001):

Os quatrocentões aqui em São Paulo, a gente vê essas casas superantigas no Jardim América e Europa [...]. As casas aqui são de cinquenta, sessenta anos, e são clássicas [...]. Muitas casas são clássicas, então o que é que acontece, já é um gosto que vem [...]. Esse clássico das pessoas ricas que sempre moraram aqui nos Jardins (América, Europa, Paulistano). Então já vem de geração para geração. Então quando eles saem de uma casa, eles procuram um prédio que tenha mais ou menos a mesma característica da casa que eles viveram e que os pais viveram. (Entrevista realizada em 12.6.2012)

Se, no âmbito da arquitetura horizontal, os grupos abastados teriam associado tal forma de morar ao que há de mais luxuoso ("É uma casa grandiosa, pé direito alto, que tem janelões, um jardim bonito"), tal também seria válido na arquitetura de apartamentos. Referindo-se aos prédios de alto padrão projetados por Pablo Slemenson e erguidos pela São José, observa: "São extremamente imponentes, luxuosos, às vezes o hall de entrada revestido todo de madeira, então é tudo muito... Que remete a poder, ao luxo, né? [Mais] do que um prédio que às vezes é mais limpo, mais clean, que é tão caro quanto". Evocando o processo de "alquimia social" que opera a "separação da fabricação do bem material e a produção do bem simbólico" (Bourdieu; Delsaut, 2006, p.163), ele nota que "[...] quanto mais informação, quanto mais rococó, quanto mais aquele beiral todo trabalhado, parece que o produto é melhor, né, ele é mais chique, ele é mais caro, ele é mais poderoso, do que uma fachada modernista que também é legal, e às vezes o prédio é até melhor".

Depois de mencionar um conjunto de edifícios "neoclássicos" projetados por Adolpho Lindenberg na Rua Cristovão Diniz - e que seriam muito valorizados - ele precisa que:

[...] os novos-ricos, eles querem coisa nova, prédio recém-lançado. Tem uma diferença muito grande, porque o rico mesmo, que vem de berço, 
que já morou aqui nos Jardins, ele procura o neoclássico. Tem muita gente que tem dinheiro, que está ganhando dinheiro agora com o mercado financeiro, jovens de trinta e poucos anos que estão ficando ricos, às vezes não querem [...]. Preferem uma fachada moderna, com uma varanda gourmet.

Vê-se, nesse relato, que a criação de uma antiguidade através da arquitetura é estratégia distintiva dos ricos “de berço", chegando ao paroxismo de evitar a manutenção:

O beiral do prédio, ele vai escurecendo, ele vai encardindo, ele vai ficando preto, e os moradores não querem pintar. E não é por falta de dinheiro. É para mostrar que aquele prédio é antigo, que aquele prédio está há anos ali, tem uma tradição, que ali as famílias, as gerações vão passando no mesmo prédio.

Se não há, pois, consenso quanto às frações das elites que mais aderem ao partido arquitetônico em pauta - e se apenas um levantamento estatístico dos moradores desses prédios poderia fornecer uma resposta a tal questão -, algumas hipóteses podem ser aventadas. A representatividade das fachadas classicizantes num catálogo de imóveis comercializados por uma agência atuante no setor de luxo (em bairros como Jardim Europa, Jardim América, Jardim Paulista, Cidade Jardim, Jardim Guedala e Vila Nova Conceição) parece fundamentar as afirmações de um de seus corretores, que insistiu na associação entre esse gosto e as classes altas de São Paulo, e também no fato de que os prédios "neoclássicos" se beneficiam do prestígio angariado pela linguagem clássica no âmbito da arquitetura horizontal. Esse catálogo que faz parte dos materiais enviados às "pessoas importantes" traz, já em sua capa, a imagem de uma mansão clássica projetada por Marcos Tomanik no Morumbi. Na parte consagrada às casas, há um capítulo todo dedicado aos feitos da arquiteta Bi Crisóstomo, que já teria projetado 450 casas, $80 \%$ delas clássicas: "Sua preferência pelo estilo clássico vem da cultura italiana, adquirida quando estudou pintura em Roma, antes de se tornar arquiteta [...]. Para Bi, o estilo clássico conquista as pessoas e é unanimidade no mercado, pois não sai de moda, é atemporal" (p.85). ${ }^{9}$ Na parte dedicada à arquitetura de apartamentos, nota-se que dos trinta edifícios apresentados, ao menos 22 são "neoclássicos" $(73,3 \%)$, três apresentam uma arquitetura externa moderna, um não tem qualquer especificidade e quatro carecem de fotos ou textos que deem a ver sua “embalagem estética”. Além de conter imagens dos prédios que têm apartamentos à venda, há ilustrações de quatro outros edifícios acompanhando os textos e, desse total, três são "neoclássicos".

Tendo estudado a recepção das torres d'Aillaud, em Nanterre, sociólogos da arquitetura franceses mostraram que a torre é símbolo de sucesso social quando de sua proposição à sociedade, mas, mesmo mantendo suas propriedades intrínsecas, tem sua imagem social profundamente afetada depois de generalizado o seu modelo nos bairros desfavorecidos (Eleb; Nivet; Violeau, 2005, p.101). 
Estudos como esse mostram como a análise dos condicionantes socioculturais subjacentes ao triunfo de um modelo de habitação exige que se identifiquem suas clientelas preferenciais, pois um mesmo imóvel adquire significados distintos segundo o estatuto social de seu morador. Se tal é o caso, há que frisar que embora os prédios "neoclássicos" de São Paulo tenham experimentado certa desvalorização dada à sua relativa popularização (Fioratti, 2012), ${ }^{10}$ tal processo não anulou sua presença no espaço residencial das elites paulistanas, e notadamente junto às frações mais ricas em capital econômico. Baseado em dados recolhidos pelo site "Informações Imobiliárias Imediatas", o site da Revista Exame divulgou a matéria "Palácios urbanos", que informou que nove dentre os dez edifícios residenciais mais caros da cidade filiam-se ao chamado "estilo neoclássico" (Wiltgen, 2012).

Por fim, outro indício de que as frações das classes altas mais ricas em capital econômico estão a acolher esse tipo de moradia figura no site da Construtora São José. Malgrado o fato de encontrarmos, em meio à totalidade das construções da empresa (hotéis, condomínios residenciais, conjuntos comerciais etc.) variados tipos de arquitetura, o ícone "alto padrão" nos direciona aos empreendimentos "Condomínio Arthur Ramos", "Residencial Franz Schubert", "Condomínio George Sand", "Condomínio Frédéric Chopin" e "Monreale" (sic), todos projetados no chamado "estilo neoclássico".

\section{$\mathrm{O}$ desgosto do modernismo}

Considerando-se que toda proposta cultural se define, sobretudo, naquilo que recusa (Bourdieu, 1996), pode-se dizer que o partido eclético e decorativo que dá o tom de uma parte da produção arquitetônica contemporânea situa-se em oposição a certos cânones do modernismo. Tendo pesquisado as preferências arquitetônicas dos habitantes de um prédio desacreditado pelos arquitetos (devido ao ecletismo construtivo e licenciosidade formal), porém bem acolhido pelos profissionais de marketing na Paris dos anos 2000, Monique Eleb, Soline Nivet e Jean-Louis Violeau sublinharam que a maioria dos moradores rejeita a austeridade das propostas modernas, vistas como algo não confortável e pouco aconchegante. Segundo os autores, o grande público não exposto às escolas e aos movimentos arquitetônicos recusa a uniformidade das fachadas sem ornamentos, pois, enquanto as superfícies planas exigiriam um único centramento do olhar, as fachadas protuberantes e repletas de elementos decorativos demandariam muitas fixações do olhar, num contexto em que quanto mais se centra o olhar, mais se valoriza o que se vê (Eleb; Nivet; Violeau, 2005, p.59-60). O desgosto por uma estética associada ao modernismo arquitetônico também figura em outro estudo francês sobre os usuários da arquitetura, que mostrou que uma fachada de concreto aparente é rejeitada pelos mais diversos segmentos sociais (Barbe; Duclent, 1986).

No âmbito de nossa pesquisa, um arquiteto responsável pelos projetos dos prédios "neoclássicos" erguidos pela Kauffman fez coro com aqueles que 


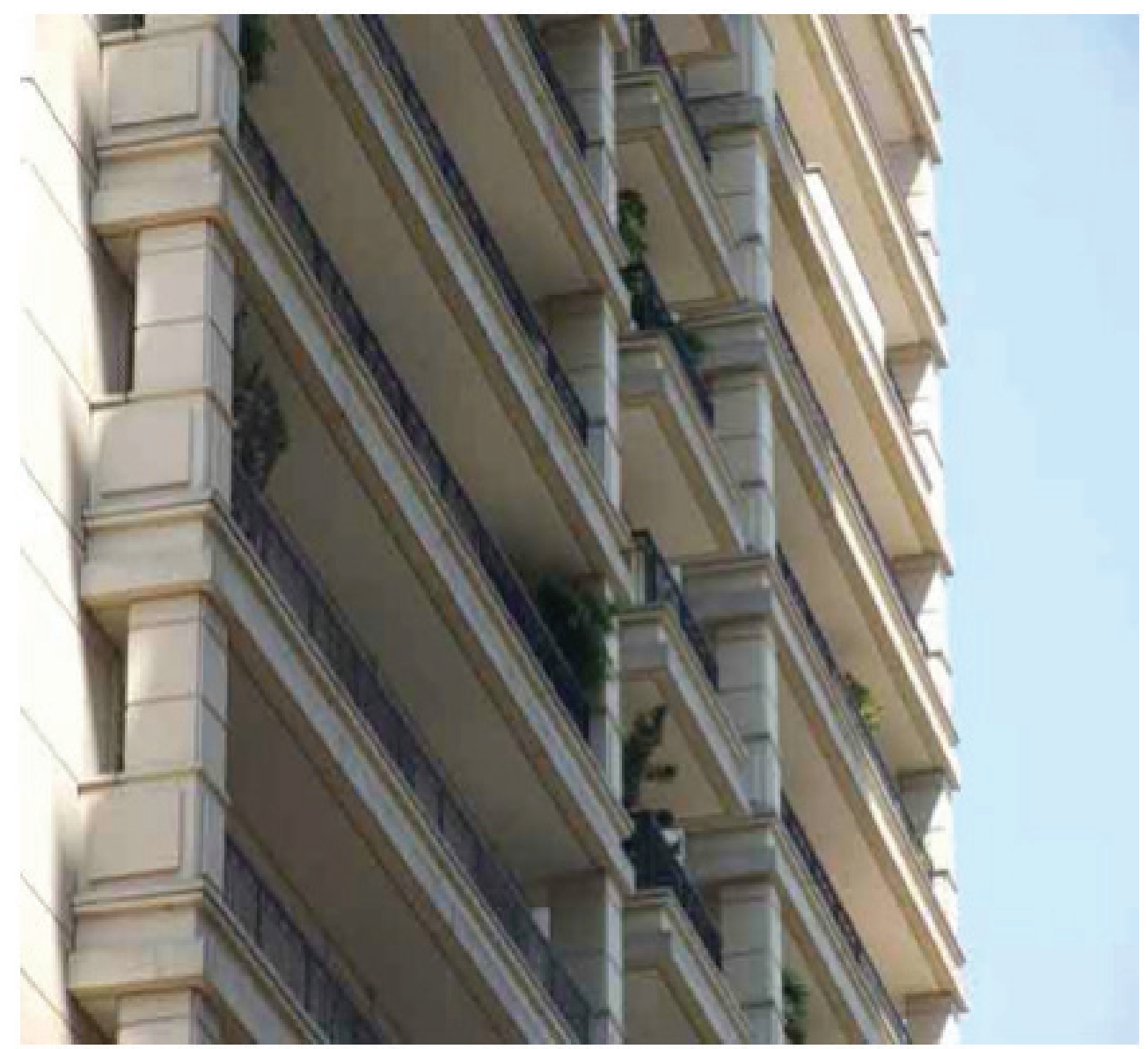

Foto $9^{\circ}$ lugar: L'Essence Jardins - “Os apartamentos têm, no mínimo, 500 metros quadrados, quatro suítes e seis vagas na garagem. Os condomínios contam com segurança 24 horas, revestimentos de mármore e granito, e áreas de lazer que incluem piscinas aquecidas, spa, jardins e até quadras de tênis. Os edifícios milionários de São Paulo abrigam famosos, banqueiros e grandes empresários e parecem verdadeiros palácios urbanos, localizados não em bairros isolados, mas em regiões centrais da cidade, perto dos grandes centros financeiros e comerciais [...]. O edifício de 35 andares em estilo neoclássico localizado na Rua Haddock Lobo, no Jardim América, conta com apartamentos de 734 metros quadrados, cinco suítes, um amplo living ligado a um terraço de mármore e oito vagas na garagem. O preço médio dessas unidades está em 16,5 milhões de reais, cerca de 22.500 reais por metro quadrado. O menor valor de avaliação é de 14 milhões de reais, e o maior, de 19 milhões de reais. Uma cobertura no L'Essence que fica no coração dos Jardins tem 1.098 metros quadrados, cinco suítes e um valor avaliado em 24,7 milhões de reais. A área de lazer do condomínio inclui uma quadra de tênis oficial e uma quadra de squash". (Wiltgen, 2012) 
responsabilizam o modernismo e a estética do concreto aparente (Huet, 1981; Culot apud Violeau, 2005; Panerai e Castex apud Violeau, 2005) pela emergência da linguagem arquitetônica passadista, eclética e decorativa na contemporaneidade:

Pega, por exemplo, um prédio de concreto aparente. Ele é um prédio que se deteriora, fica feio [...]. Eu morei muitos anos no Portal do Morumbi, é todo de concreto aparente [...], a fachada de concreto aparente dava muito problema. Por que o que acontece? O concreto aparente, além do que, por conta da poluição... Hoje mudou, o recobrimento do ferro é maior, mas na época era menor, então a poluição agride o ferro, e vai enferrujando inclusive. Então quando você via tratar a fachada, não era só um problema de pintura, de verniz não. Eu morei lá, você não sabe o barulho que era aquilo, uma britadeira, eles tinham que recortar o concreto, trocar os pedaços de ferro que estavam totalmente enferrujados [...]. E ficou horrível, você olha para ele, está todo remendado. ${ }^{11}$

Com efeito, em relação aos principais referenciais dispostos no universo da habitação, a proposta "neoclássica" parece definir-se, sobretudo, na recusa da arquitetura moderna. Apesar de insistir nas explicações de ordem econômica ("eu não uso muito alumínio, eu posso usar ferro nos gradis, que é bem mais barato") e/ou técnica ("a massa corrige qualquer coisa, qualquer imperfeição de construção"), um arquiteto-paisagista valorizado pelo mercado não deixa de reconhecer que "o neoclássico tem algumas vantagens que o pessoal do moderno não consegue entender". E dentre essas vantagens, aquela que o entrevistado mais salienta é o que ele chama de "envelhecer com dignidade". Assim, se os prédios comuns de Brasília, com suas lajes planas, sofrem graves problemas de infiltração, “[...] esses prédios neoclássicos, quanto mais velhos eles ficam, eles ficam mais bonitos". Se, com o tempo, os materiais utilizados na arquitetura moderna ficariam “mais corroídos”, o edifício (dito) neoclássico “[...] envelhece bem e ele traz essa ideia de que o imóvel é um patrimônio [...], ele traz toda essa coisa dos palácios", num contexto em que “as pessoas gostam de se sentir um pouco reis".

$\mathrm{Na}$ opinião de outro paisagista envolvido com a produção dessa arquitetura doméstica, a rejeição ao projeto de residência filiado aos princípios do moderno também teria contribuído para que os prédios "neoclássicos" se legitimassem. Convencido da dificuldade inerente à definição do perfil da clientela de um determinado gosto arquitetônico, ele evoca o caso de uma herdeira das elites nacionais que mora numa casa clássica, mas se hospeda em hotel moderno. E frisa que "muita gente fala assim 'Ah, eu acho legal o moderno para uma viagem, para ir à casa do amigo [...], mas não para eu morar'”. Tal como outros entrevistados, ele considera que a arquitetura moderna resiste mal ao tempo: “[...] pega uma casa brancona do Flores, enfim, do pessoal, do Isay, do Marcio Kogan, de cinco anos atrás e vai ver como está [...]; está feio, a manutenção é maior. Pega uma casa neoclássica de trinta anos atrás [...] e vê se não está boni- 
ta". Nessa mesma linha de juízo, ele confessa já ter ouvido vários moradores de casas modernas reclamarem da falta de aconchego dessa proposta de habitação.

Tendo em vista que, segundo os corretores e construtores entrevistados, outra "conveniência" dos edifícios "neoclássicos" residiria no fato de que sua planta seria também rigorosamente clássica ("A distribuição é ortodoxa, clássica, você tem a área social, você tem a área íntima, você tem a área de serviço, você tem a ligação da área íntima para a área de serviço sem passar pela sala, você tem a varanda, você tem as dependências... Muito clássico, ao passo que o contemporâneo, o moderno, você ousa muito mais"), poder-se-ia perguntar se a resistência à planta livre que atenua a separação entre o "setor social" e o "setor de serviços" - e, consequentemente, nossas arraigadas formas hierárquicas de sociabilidade - não explicaria, ao menos parcialmente, esse desgosto do modernismo. ${ }^{12}$

\section{A adesão envergonhada}

Em discussão com os que advogam, um pouco precipitadamente, o fim das hierarquias em matéria de cultura - e que parecem questionar a própria existência de uma distinção entre o bom ou o mau gosto -, o sociólogo Louis Pinto (2009) lembra que há diferentes modalidades de relacionamento com os bens culturais por assim dizer menos nobres: ocasional ou durável, assumida ou envergonhada, e assim por diante. Em vista de tal consideração, parece-nos importante sublinhar que os profissionais envolvidos com a produção e difusão de edifícios "neoclássicos" emitem, com frequência, uma narrativa envergonhada advinda, justamente, da atuação na promoção dessa proposta bem-sucedida em termos comerciais: "Eu por acaso moro num prédio neoclássico que foi construído pela Tecnisa e pela Cyrela [...]. Eu ajudei até um pouquinho a Tecnisa adotar o modelo neoclássico e hoje para ser sincero eu não gosto" (engenheiro civil atuante na Secretaria de Habitação e ex-gerente de negócios da Tecnisa). Quando ele revelou morar em Alto de Pinheiros, nós perguntamos se ele residia no condomínio Les Jardins de Bourgogne, ao que ele respondeu afirmativamente, mas não sem justificar que ele se mudara de Higienópolis para esse residencial "neoclássico" devido ao fato de seus filhos estudarem no Colégio Santa Cruz e poderem então ir a pé à escola.

Promotores de uma das arquiteturas de maior sucesso comercial, eles não obstante se situam recorrentemente em relação à arquitetura erudita e/ou de vanguarda, que no mais das vezes é associada aos feitos modernistas e aos arquitetos da FAU-USP. Como se estivesse a atestar o quanto o chamado "estilo neoclássico" ocupa uma posição dominada do ponto de vista de um reconhecimento propriamente simbólico, uma arquiteta e gerente de projetos da Construtora Adolpho Lindenberg fez questão de enfatizar que a CAL não constrói nem nunca construiu apenas edifícios filiados a tal partido arquitetônico, tendo se esmerado em comentar minuciosamente cada um dos prédios modernistas de autoria da construtora. Mesmo quando se empenha em expor as qualidades dos 
prédios ornamentados, o referencial de boa conduta é o modernismo, com seus princípios de que o menos é mais e de que a forma segue a função:

O que é que é bonito no neoclássico? Eu acho que é o gradil, o trabalho dos portões, das portas de entrada, o gradil de ferro, as cornijas, as molduras [...]. Não necessariamente muita moldura, muito ornamento, não necessariamente isso. Mas aquele ornamento bem feito, bonito, que causa impacto. $\mathrm{O}$ portão trabalhado. Eu acho que isso aí é o que causa... a gente tem as bases que são trabalhadas, que são aqueles fulgets... Ele existe para proteger a arquitetura quando cai uma chuva, respinga barro e aquilo ali é mais fácil de limpar, ele tem uma função, ele não é só embelezamento.

Outra evidência de que tais construções "neoclássicas" se encontram numa posição dominada do ponto de vista de sua legitimidade cultural - embora dominante no âmbito da hierarquia que corre no bojo do mercado - revela-se no fato de que, como os demais arquitetos entrevistados, ela faz questão de dizer que não nutre uma preferência pessoal por esse partido arquitetônico: "Eu, sinceramente, eu amo o contemporâneo, por mim eu faria só contemporâneo, mas eu tenho respeito $[. .$.$] pelo que eu faço... pelo que o mercado pede".$

Certa indignidade cultural emerge claramente nas falas de arquitetos e/ ou paisagistas que, tendo sido educados segundo os cânones do modernismo, acabaram por abrir mão, ao longo da trajetória profissional, de suas convicções iniciais. As narrativas sobre a participação nesses empreendimentos de alta rentabilidade econômica são carregadas de sentimentos de vergonha, já que o informante se sente no dever de justificar a decisão de projetar prédios "neoclássicos", valendo-se de argumentos que vão desde o intuito de satisfazer os desejos dos usuários da arquitetura até o imperativo de não perder um cliente de antemão decidido a pagar pelo projeto de um imóvel desse gênero. Assim é que um antigo aluno da FAU-USP deu início à entrevista referindo-se às pressões que pesam sobre o arquiteto que deve, muitas vezes, fazer o que não quer para sobreviver:

Eu resisti, resisti, até que um cliente começou a fazer um trabalho comigo e falou "Olha, esse projeto tem que ser neoclássico porque se você não fizer eu vou ter que contratar o Adolpho Lindenberg para fazer. Então você escolhe, ou faz e continua com a gente ou eu vou ter que contratar". Então eu fiquei acuado e falei "Bom, já que é para fazer eu vou fazer". Procurei, dentro dessa demanda, fazer alguma coisa que misturasse um pouco o neoclássico com uma coisa moderna.

Ele que afirmou com desgosto ter tido que ceder ("Não faço arquitetura neoclássica por prazer") fez questão de dizer que embora esteja envolvido com a produção desses edifícios, não gosta nem moraria num deles.

Se o projeto de prédios "neoclássicos" envergonha, a adoção de soluções modernistas reestabelece o amor-próprio. Assim é que, apesar de ter dito, como Jameson (1996), que a arquitetura resultante do chamado historicismo pós- 
-moderno era decepcionante, ele próprio não se furtou à mistura de linguagens e elementos cara ao "pós-modernismo":

Nós fizemos outro [prédio], que foi uma brincadeira também, de mistura de neoclássico com moderno. Eu não gostei muito, mas enfim. Tem uma parte dele neoclássica e uma parte moderna. Ficou meio estranho, mas assim eu achei que era até uma conquista, quer dizer, estávamos rompendo com o neoclássico.

A entrevista com um arquiteto-paisagista envolvido com a produção de edifícios "neoclássicos" também ilustrou o quanto os arquitetos filiados aos princípios do moderno ocupam uma posição dominada do ponto de vista econômico, porém dominante do ponto de vista simbólico. Ou seja, por um lado, o informante considera inócua a crítica de "arquitetura passadista" que os modernistas dirigem aos prédios "neoclássicos" construídos na atualidade, pois de um ponto de vista efetivo não são eles que fazem a produção arquitetônica, já que não seriam contratados pelas empresas que realmente detêm o poder social de construir. Por outro lado, no entanto, parece concordar com a tese de que há uma "hegemonia modernista" (Ficher, 2007, p.4) no âmbito das instâncias de poder propriamente simbólico, já que tal supremacia, presente já na organização da profissão de arquiteto, se reproduziria no ensino institucional, nos textos de história da arquitetura, na crítica arquitetônica e no próprio entendimento do que é arquitetura. Tanto haveria tal superioridade simbólica que, mesmo denunciando os arquitetos que ele considera "intransigentes" ("não adianta pensar em projetos maravilhosos que não vendam, porque isso significa que o projeto será abortado"), ele revela ter tido uma profunda crise existencial quando decidiu renegar alguns valores reinantes na FAU-USP para se tornar um profissional bem-sucedido do ponto de vista do mercado. E assume que foi muito criticado por fazer projetos paisagísticos para empreendimentos "neoclássicos", e que todas essas críticas o incomodaram muito, o que o impulsou a fazer psicanálise durante anos. Como os demais informantes, aliás, ele fez questão de precisar que apesar de fazer o paisagismo desses residenciais, ele próprio nunca moraria num deles.

Tendo renunciado ao reconhecimento advindo dos meios intelectuais e artísticos e se submetido às necessidades de rentabilidade imediata do mercado imobiliário, ele sublinha que este sempre procura soluções valorizadas pelos compradores e pouco onerosas para os produtores, de modo que o sucesso do chamado "estilo neoclássico" em São Paulo explicar-se-ia pelo valor que a sociedade atribui à evocação de uma arquitetura palaciana, mas, simultaneamente, pelo baixo custo dessa arquitetura que não exige muita manutenção nem mão de obra muito qualificada. Nota-se, aqui, que a aposta "neoclássica" deixa de ser algo que "envelhece com dignidade", como dissera anteriormente, para ser a única opção viável num país cuja mão de obra é de baixa qualidade. Ao evocarmos a polêmica entre Carlos Lemos e Adolpho Lindenberg (Duran, 2000) 
sobre qual era a arquitetura mais custosa, ele narrou episódios que atestavam como o modernismo arquitetônico exige trabalhadores e materiais mais sofisticados (Durand, 1989), enquanto "uma arquitetura neoclássica, ela é massa, ela está mais compatível com a nossa mão-de-obra que é analfabeta". ${ }^{13}$

Mesmo um corretor atuante no ramo de alto padrão que afirmara que "uma fachada imponente sempre chama mais atenção" acabou por apontar a ilegitimidade desse gosto ao precisar, logo em seguida, que tal asserção era especialmente válida para "a pessoa que não entende", associando inevitavelmente tal preferência a uma falta de cultura arquitetônica.

Finalmente, o maior indício de que os promotores do modelo de moradia em discussão se definem pela maior facilidade de acesso às encomendas privadas, mas, simultaneamente, pelo menor reconhecimento simbólico emerge no testemunho de um engenheiro civil e proprietário-presidente de uma das construtoras que produzem edifícios residenciais "neoclássicos" de alto padrão. Por um lado, ele exprime bastante bem o suposto de que as diferentes visões a respeito do fenômeno correspondem às não menos diversas posições no campo da arquitetura, na medida em que, na condição de construtor, ele se orgulha de estar à frente da difusão de uma arquitetura que remete ao "estilo de vida da nobreza" e que, quando bem feita, "é uma verdadeira obra de arte". Por outro, quando discorre sobre a perda de espaço dos "neoclássicos" nos lançamentos das grandes construtoras, ele acaba por assumir que tal mudança se deveu à adulteração excessiva dos edifícios inscritos sob o rótulo do "neoclássico", mas, também, ao fato de que as pessoas estariam cada vez mais informadas a respeito de arquitetura. Ora, se a posse de um maior conhecimento em matéria de arquitetura impacta diretamente a afeição pelas fachadas "neoclássicas", então é porque tal proposta de habitação está mal posicionada na hierarquia dos valores culturais. Como se estivessem a atestar que o maior sucesso mercadológico pode levar também ao maior descrédito (Bourdieu, 1996), as representações dos artífices desse partido arquitetônico acabam por evidenciar, talvez ainda mais do que os discursos de seus assumidos opositores, como este é um gosto dominado do ponto de vista simbólico, ou simplesmente um mau gosto.

\section{Considerações finais}

A exposição dos primeiros resultados de uma pesquisa sobre os condicionantes socioculturais da proliferação de edifícios "neoclássicos" na arquitetura de apartamentos de São Paulo discutiu alguns fatores que escapam a uma explicação exclusivamente técnica e/ou econômica e que dizem respeito à produção da crença nesse modelo de habitação. Ainda que não tenhamos resultados conclusivos, o exame dos discursos emitidos por diferentes profissionais envolvidos na promoção desse gosto controverso sugere que as virtudes desses prédios advêm não tanto de suas propriedades intrínsecas, mas dos sentimentos que evocam e simbolizam. Num contexto urbano marcado pela presença maciça de "meras construções", a mobilização de categorias históricas como argumento 
de venda, a pré-fabricação de cenários de aparência tradicional e o uso de elementos arquitetônicos "marcados pela História" satisfazem a uma preferência supostamente inspirada nos padrões europeus de moradia (e na vida aristocrática que presumem simbolizar). Escravizados às expectativas de estima social dos moradores, tais imóveis testemunham o valor atribuído à evocação de uma arquitetura palaciana e, também, as tentativas de criação de uma antiguidade através da arquitetura.

Nossa pesquisa dará todos os seus frutos quando dispusermos dos dados necessários à construção do espaço estruturado representado pelo campo da arquitetura. A rigor, as declarações e profissões de virtude que depreendem das entrevistas (e da crítica arquitetônica) só podem ser plenamente compreendidas levando-se em conta a posição que cada informante ocupa no campo da arquitetura como um todo e no subcampo da arquitetura representado por todos os demais promotores do "neoclássico", ou seja, por todos os demais agentes com os quais concorrem pelo monopólio da legitimidade em matéria de habitação. Nesse sentido, conviria empreender ainda um levantamento estatístico das clientelas desses empreendimentos, pois, se, por um lado, a produção produz o consumidor, anulando os outros modos possíveis de satisfazer à necessidade de habitar, por outro, os agentes dotados do poder social de construir adaptam suas práticas às estruturas de percepção coletivas, sobretudo em se tratando da arquitetura doméstica que, como se sabe, cristaliza as práticas e representações de seus usuários que preexistem à elaboração do projeto arquitetônico (Segaud, 1988).

\section{Notas}

1 Este artigo apresenta resultados preliminares de uma pesquisa de pós-doutorado realizada no Museu Paulista da USP entre 2011 e 2012 sob os auspícios da Fundação de Amparo à Pesquisa do Estado de São Paulo (Fapesp).

2 Não é um acaso, pois, que o engenheiro-arquiteto Adolpho Lindenberg, um dos nomes mais associados ao chamado "estilo neoclássico", tenha recebido uma homenagem na edição 2011 do Prêmio Master Imobiliário (Scheller, 2011) e, não, uma distinção outorgada por uma das instâncias de consagração do campo da arquitetura. Outro indício de que estamos diante de um construtor pouco reconhecido pelos arquitetos e bastante dependente de sua clientela privada reside no fato de que o livro Construtora Adolpho Lindenberg 50 anos foi editado pela própria construtora a fim de presentear seus clientes.

3 A propósito, uma pesquisa encomendada pela Construtora Adolpho Lindenberg mostrou que sete entre dez paulistanos de alto poder aquisitivo preferem fachadas neoclássicas (Visoni; Mourão; Reinés, 2004).

$4 \mathrm{Na}$ Rua Frédéric Chopin, os apartamentos nos edifícios Franz Schubert, George Sand e Frédéric Chopin têm $621 \mathrm{~m}^{2}, 680 \mathrm{~m}^{2}$ e $585 \mathrm{~m}^{2} \mathrm{e}$ custam - segundo o site Informações Imobiliárias Imediatas - R \$ 18.228.423,85; R\$ 17.499.482,65 e R\$ 17.207.093,40 (Disponível em: <http://www.123i.com.br> Acesso em: 6 jun. 2012). 
5 Esta é uma montagem feita a partir do texto e da imagem divulgados no site da Construtora Tecnisa, que produziu o empreendimento junto da Construtora Cyrela (Disponível em: <http://www.tecnisa.com.br/imovel-residencial-apartamento-jardins-sao+paulo-le+crillon.html>. Acesso em: 8 jun. 2012). Entre 1996 e 2000, 72\% dos empreendimentos lançados pela Cyrela foram construídos em "estilo neoclássico". Dos quatorze empreendimentos lançados pela Tecnisa em 2002, todos apresentam uma fachada "neoclássica" (Duran, 2000; Lemos, 2002).

6 Disponível em: <http://www.kauffmann.com.br/imovel.aspx?id=500031>. Acesso em: $1^{\circ}$ set. 2012.

7 Sobre a criação de uma tradição através da arquitetura na Inglaterra de fins do XIX, ver Dellheim (1982).

8 Apesar de se referir à "grande mistura", à verdadeira "salada russa" que caracteriza hoje algumas construções inscritas sob o rótulo do "neoclássico", ele se mostra conivente com a mistura de linguagens e elementos propagada pelo pós-modernismo arquitetônico, com seus valores do hibridismo radical e da rejeição das estéticas integradas (Jencks, 1987). Assim, ao discorrer sobre o paisagismo monumental que seu escritório propôs a um conjunto residencial "neoclássico", assume que em certos pontos do terreno o visual "já está mais espanhol, ou mais mouro" e que uma coerência total pode ser algo muito ortodoxo, pois “quem está aqui não está lá”.

9 Não forneceremos a referência bibliográfica para não comprometer o anonimato que garantimos ao informante.

10 A queda de encomendas de edifícios "neoclássicos" veio à tona em todas as entrevistas realizadas.

11 Confirmando o que a crítica de arquitetura anunciara, isto é, que o ensino do modernismo julga dispensável transmitir um conhecimento efetivo da arquitetura clássica (Dowling, 2004; Teperman, 2007), ele diz ter tido que estudar quando começou a projetar prédios evocadores dessa linguagem: "E você começa a ver que tem certa proporção, que dá o equilíbrio, né, você vai para Paris e tem toda aquela arquitetura neoclássica". Tendo visitado, no Canadá, prédios de fachadas neoclássicas compostas de elementos pré-moldados, ele se inspirara ainda nos feitos de Ricardo Bofill, célebre praticante das expressões neoclássicas na arquitetura contemporânea.

12 Sobre a rejeição ao modernismo arquitetônico entre as elites de São Paulo, ver Pulici (2011).

13 Quando se atenta para a visão de mundo que vai de par com a promoção dos prédios "neoclássicos", nota-se que a clivagem entre tradicionalistas e modernistas pode não ser apenas de ordem estética. No caso de Adolpho Lindenberg, pode-se lançar a hipótese de que seu respeito de certa tradição clássica dá a ver disposições estéticas, mas, também, ideológicas. Morador de um edifício "neoclássico" em Higienópolis, ele é um dos financiadores da associação "Tradição, Família e Propriedade", cujo fundador foi seu primo, a quem dedicou o livro Os católicos e a economia de mercado. Nessa obra que reivindica o expurgo de "clichês marxistas" na visão do capitalismo, evidencia-se sua admiração pelo Antigo Regime: "O mundo anterior à Revolução Francesa alicerçava-se em valores espirituais que o processo revolucionário demoliu em grande parte. Honra, dignidade, distinção, cultura, brilho intelectual, educação, afabilidade, savoir-pivre, eram valores superiores, que gradualmente foram sendo deglutidos pela difusão do espírito revolucionário. Com razão afirmou Talleyrand, o grande diploma- 
ta francês do tempo de Napoleão e Luís XVIII [...]: 'Quem não viveu antes de 1789 não conheceu a doçura de viver'” (Lindenberg, 2002, p.73-4). Sobre como o espaço dos possíveis arquitetônicos só adquire pleno sentido quando referido às oposições do campo político, ver Pinto (1991).

\section{Referências}

BAILLY, J.-C. Préface. In: LOYER, F. Paris XIXe siècle: l'immeuble et la rue. Paris: Hazan, 1987.

BARBE, B.; DUCLENT, A. Le vécu de l'architecture. Paris: Ministère de l'Équipement, du Logement, de l'Aménagement du Territoire et des Transports, 1986.

BERNARD, L. Le capital culturel non certifié comme mode d'accès aux classes moyennes : l'entregent des agents immobiliers. Actes de la Recherche en Sciences Sociales, n.191192, p.68-85, 2012.

BIAU, V. La consécration en architecture: l'émergence de nouvelles élites architecturales en France. 2000. Thèse (Doctorat de Sociologie) - École de Hautes Études Sciences Sociales. Paris, 2000.

BOURDIEU, P. As regras da arte. Gênese e estrutura do campo literário. São Paulo: Cia. das Letras, 1996.

. Les structures sociales de l'économie. Paris: Seuil, 2000.

BOURDIEU, P.; DELSAUT, Y. O costureiro e sua grife: contribuição para uma teoria da magia. In: BOURDIEU, P. A produção da crença: contribuição para uma economia dos bens simbólicos. Porto Alegre: Zouk, 2006.

DELLHEIM, C. The face of the past: the preservation of the medieval inheritance in Victorian England. Cambridge: Cambridge University Press, 1982.

DOWLING, E. M. New classicism: the rebirth of traditional architecture. New York: Rizzoli International Publications, 2004.

DURAND, J. C. Arte, privilégio e distinção. Artes plásticas, arquitetura e classe dirigente no Brasil, 1855/1985. São Paulo: Perspectiva; Edusp, 1989.

DURKHEIM, E. As formas elementares da vida religiosa. São Paulo: Martins Fontes, 1996.

ELEB, M.; NIVET, S.; VIOLEAU, J.-L. L'architecture entre goût et opinion: construction d'un parcours et construction d'un jugement. Paris: Laboratoire Architecture, Culture et Sociétés; École Nationale Supérieure d'Architecture, 2005.

ELIAS, N. A sociedade de corte: investigação sobre a sociologia da realeza e da aristocracia de corte. Rio de Janeiro: Zahar, 2001.

ELIAS, N.; SCOTSON, J. Os estabelecidos e os outsiders: sociologia das relações de poder a partir de uma pequena comunidade. Rio de Janeiro: Zahar, 2000.

FICHER, S. Reflexões sobre o pós-modernismo. MDC, n.4, p.3-17, 2007.

GOMBRICH, E. H. La force de l'habitude. In: . Gombrich: l'essentiel. Écrits sur l'art et la culture. Paris: Phaidon, 2003. p.223-56.

HUET, B. Anachroniques d'architecture. Bruxeles: AAM Éditions, 1981. 
JAMESON, F. Arquitetura: equivalentes espaciais no sistema mundial. In: . Pós-modernismo: a lógica cultural do capitalismo tardio. São Paulo: Ática, 1996. p.119-48. JENCKS, C. Post-modernism: the new classicism in art and architecture. London: Academy Editions, 1987.

LEITE, L. R. P. Estudo das estratégias das empresas incorporadoras do município de São Paulo no segmento residencial no período 1960-1980. 2006. Dissertação (Mestrado em Arquitetura) - Faculdade de Arquitetura e Urbanismo, Universidade de São Paulo. São Paulo, 2006.

LOYER, F. Paris XIXe siècle: l'immeuble et la rue. Paris: Hazan, 1987.

PINHEIRO, M. L. B. Arquitetura residencial verticalizada em São Paulo nas décadas de 1930 e 1940. Anais do Musen Paulista, v.16, 2008.

PINTO, L. Déconstruire Beaubourg: art, politique et architecture. Genèses, n.6, p.98$124,1991$.

Não multiplicar o indivíduo inutilmente. Lua Nova, n.77, p.205-25, 2009.

PULICI, C. O gosto dominante como gosto tradicional: preferências e aversões estéticas das classes altas de São Paulo. Novos Estudos Cebrap, n.91, p.123-39, 2011.

REIS FILHO, N. G. Quadro da arquitetura no Brasil. São Paulo: Perspectiva, 1987.

SCHORSKE, C. E. Fin-de-Siècle Vienna: politics and culture. New York: Vintage Books Edition, 1981.

SEGAUD, M. Esquisse d'une sociologie du goût en architecture. 1988. Thèse (Doctorat d'État) - Université Paris X. Nanterre, 1988.

TRIGO, M. H. B. Os paulistas de quatrocentos anos: ser e parecer. São Paulo: Annablume, 2001 .

VILLA, S. B. O produto imobiliário paulistano: uma crítica à produção de apartamentos ofertados no mercado imobiliário a partir de 2000. 2006 (mimeo). Disponível em $<$ http://www.lares.org.br/2006/artigo\%20Simone\%20Villa\%20vfinal.doc>. Acesso em: 6 set. 2010 .

VIOLEAU, J.-L. Les architectes et mai 68. Paris: Éditions Recherches, 2005.

WARCHAVCHIK, G. Arquitetura do século XX e outros escritos. São Paulo: CosacNaif, 2006.

Fontes documentais

CORREA, V. Arquitetura de SP embarca no estilo contemporâneo. Folha de S.Paulo, 22.5.2011, p.C1-C3.

DURAN, S. Estilo segue atual, diz o “criador". Folha de S.Paulo, 30.7.2000. Disponível em: <http://wwwl.folha.uol.com.br/fsp/imoveis/ci3007200002.htm>. Acesso em: 27 out. 2011.

Neoclássico é curinga no mercado de São Paulo. Folha de S.Paulo, 30.7.2000.

Disponível em: <http://wwwl.folha.uol.com.br/fsp/imoveis/ci3007200001.htm>. Acesso em: 27 out. 2011.

FIORATTI, G. Ascensão e queda do neoclássico. Folha de S.Paulo, 3.6.2012, p.1-2. 
HELVÉCIA, H. Passado presente: compradores adoram, arquitetos odeiam, e o estilo neoclássico vai povoando a paisagem paulistana. Revista da Folha (Morar), Folha de S.Paulo, 30.5.2008.

LEMOS, J. Em discussão, estilos de São Paulo. O Estado de S. Paulo, 22.9.2002, p.C4-C5.

LINDENBERG, A. Os católicos e a economia de mercado. Oposição ou colaboração? Considerações do bom senso. São Paulo: LTr, 2002.

MARTÍ, S.; BARROS, M. Arquitetos criticam novo neoclássico em São Paulo. Folha de S.Paulo, 6.7.2009. Disponível em: <http://wwwl.folha.uol.com.br/fsp/ilustrad/ fq0609200910.htm>. Acesso em: 2 set. 2010.

SCHELLER, F. Hoje, os bairros crescem ao redor dos shoppings. O Estado de S. Paulo, 22.9.2011. Disponível em: <http://m.estadao.com.br/noticias/impresso,hoje-os-bairros-crescem-ao-redor-dos-shoppings,775883.htm>. Acesso em: 22 set. 2011.

SERAPIÃO, F. Os edifícios-fantasmas e seus ornamentos delinquentes. Projeto Design, n.290, abril de 2004. Disponível em: <http://www.arcoweb.com.br/artigos/fernando-serapiao-os-edificios-fantasmas-20-04-2004.html>. Acesso em: 2 set. 2010.

. Projetos devem ser democráticos e expressar a nossa época. Folha de S.Paulo, 22.5.2011, p.C1-C3.

TEPERMAN, S. Arquitetonicamente incorreto, politicamente mais ainda, felizmente. Revista Arquitetura e Urbanismo, n. 157, março 2007. Disponível em: <http:// www.revistaau.com.br/arquitetura-urbanismo/157/imprime46078.asp>. Acesso em: 25 set. 2010 .

VISONI, C.; MOURÃO, L.; REINÉS, T. Construtora Adolpho Lindenberg - 50 anos. São Paulo: Conectar Comunicação, 2004,

WILTGEN, J. Os apartamentos mais caros de São Paulo. Site da Revista Exame de 14.3.2012. Disponível em: <http://exame.abril.com.br/seu-dinheiro/imoveis/noticias/os-predios-residenciais-mais-caros-de-sao-paulo? $\mathrm{p}=2 \#$ link $>$. Acesso em: 29 maio 2012 .

RESUMO - Baseado em entrevistas com diferentes profissionais (engenheiros, construtores, arquitetos, paisagistas e consultores imobiliários) envolvidos com a produção de edifícios "neoclássicos" no espaço residencial das elites de São Paulo, no material de imprensa (crítica de arquitetura, informes publicitários e sites de construtoras e corretoras imobiliárias) implicado na difusão desse modelo residencial e em fontes bibliográficas concernentes ao problema do historicismo arquitetônico, este artigo discute alguns condicionantes socioculturais desse gosto controverso. A análise dos discursos emitidos por esses agentes dotados do poder social de construir sugere que se, por um lado, tal proposta de habitação ocupa uma posição dominante do ponto de vista da hierarquia do mercado, por outro, encontra-se numa posição dominada do ponto de vista de um reconhecimento propriamente simbólico.

Palavras-Chave: Gosto, Arquitetura doméstica, Historicismo, Distinção, Elites, São Paulo. 
ABSTRACT - Based on interviews with various professionals (engineers, contractors, architects, landscapers and real estate agents) involved in the production of the so-called "neoclassical" buildings in the elite residential neighborhoods of São Paulo, on promotional material (architectural criticism, advertising brochures and websites of construction companies and realtors) that disseminate this residential model, and on bibliographical sources for architectural historicism, this article examines some sociocultural elements underlying this controversial predilection. Analyses of statements made by agents endowed with social power to build suggest that if, on the one hand, this type of housing occupies a dominant position from the viewpoint of market hierarchy, on the other hand, it occupies a dominated position in terms of symbolic recognition.

KEYWORDS Taste, Domestic architecture, Historicism, Distinction, Elites, São Paulo.

Carolina Pulicié doutora em Sociologia pela Faculdade de Filosofia, Letras e Ciências Humanas da Universidade de São Paulo; professora do Departamento de Ciências Sociais da Escola de Filosofia, Letras e Ciências Humanas da Universidade Federal de São Paulo (Unifesp). @ - carolinapulici@gmail.com

Recebido em 28.11.2013 e aceito em 8.7.2014.

I Escola de Filosofia, Letras e Ciências Humanas, Universidade Federal de São Paulo, Guarulhos/São Paulo, Brasil. 
